\title{
Tolerance of Selected Bedding Plants to Four Herbicides in Irrigation Water
}

\author{
Lyn A. Gettys ${ }^{1,2}$ and William T. Haller ${ }^{1}$
}

AdDitional INDEX wORDs. $\mathrm{EC}_{10}$, phytotoxicity, watering restrictions, quinclorac, topramezone, imazamox, penoxsulam

SuMMARY. 'Cocktail Whiskey' begonia (Begonia semperflorens), 'Sun Devil Extreme' vinca (Catharanthus roseus), 'Million Gold' melampodium (Melampodium paludosum), and 'Super Elfin' impatiens (Impatiens walleriana) plants were irrigated with water treated with quinclorac, topramezone, imazamox, and penoxsulam to identify herbicide concentrations that cause phytotoxic effects. Plants were irrigated four times over a 10-day period with the equivalent of 0.5 inch of treated water during each irrigation and were then irrigated with tap water until they were harvested 28 days after the first herbicide treatment. Visual quality and dry weight data revealed that melampodium was the most sensitive of the bedding plants to quinclorac, imazamox, and penoxsulam, whereas vinca was the most sensitive species to topramezone. Noticeable reductions in visual quality and dry weight of melampodium were evident after exposure to 240,580 , and $10 \mathrm{ppb}$ of quinclorac, imazamox, and penoxsulam, respectively, while dry weight of vinca was reduced after exposure to $110 \mathrm{ppb}$ of topramezone. Current irrigation restrictions on imazamox, penoxsulam, and topramezone are adequate to minimize damage to these bedding plants if herbicide-treated waters are used for four irrigation events. However, irrigation restrictions should be established for quinclorac to prevent damage to sensitive bedding plants such as melampodium.

$\mathrm{T}$ The number of herbicides labeled for aquatic weed control is small compared with those available for terrestrial weed management. In addition, the development of herbicide resistance has been reported in aquatic weeds, which further limits the products that provide effective weed control in lakes, ponds, and other water bodies (Koschnick et al., 2006; Michel et al., 2004). The market for aquatic herbicides is limited, and the costs associated with research and development of new chemicals are high. Thus, agrichemical companies rarely evaluate herbicides for aquatic use. However, several herbicides that are new to the aquatic market are currently being tested. Some of these herbicides

Partial support for this research was supplied by the Florida Fish and Wildlife Conservation Commission, Bureau of Invasive Species.

Mention of a trademark, proprietary product, or vendor does not constitute a guarantee or warranty of the product and does not imply its approval to the exclusion of other products or vendors that also may be suitable.

We thank Tomas Chiconela, Christopher Mudge, Brett Bultemeier, Margaret Glenn, David Mayo, and Kyle Thayer for their assistance with this research. We also thank Greg MacDonald, Jason Ferrell, and William Stall for their reviews of this manuscript.

${ }^{1}$ University of Florida Institute for Food and Agricultural Sciences, Center for Aquatic and Invasive Plants, 7922 NW 71 Street, Gainesville, FL 32653

${ }^{2}$ Corresponding author. E-mail: lgettys@ufl.edu. show great potential for the control of key weeds [e.g., hydrilla (Hydrilla verticillata), waterhyacinth (Eichhornia crassipes), and watermilfoil ( $M y r-$ iophyllum spicatum), etc.], but the effect of treated water on nontarget plants is unknown. It is therefore important to develop irrigation restrictions to avoid damage to nontarget ornamental and bedding plant species. Irrigation restrictions for herbicides applied to water have two components. The U.S. Environmental Protection Agency (USEPA) establishes acceptable concentrations or tolerances of herbicides in or on irrigated crops used for human food or animal fodder. Data are then collected to identify herbicide concentrations in irrigation water that do not exceed these rates; if rates are exceeded, a waiting period is listed on the herbicide label to prohibit water from being used for irrigation before a specified length of time. This waiting period allows the herbicide to degrade to concentrations that do not exceed the established tolerances for crops. In addition, companies may add other irrigation restrictions to reduce the likelihood of phytotoxic effects on nonfood crops.

Quinclorac is labeled for postemergence weed control in rice (Oryza sativa) and in warm- and cool-season grasses, including tall fescue (Festuca spp.), kentucky bluegrass (Poa praten$s i s)$, and others. It is a substituted quinolinecarboxylic acid that functions as an auxin mimic and stimulates the induction of 1 -aminocyclopropane-1carboxylic acid (ACC) synthase activity. Increased ACC synthase activity promotes ethylene biosynthesis; this triggers the accumulation of abscisic acid (ABA), which results in inhibited growth, epinasty, and senescence in susceptible plants (Grossmann, 1998). A Florida experimental use permit (EUP) was issued by the Florida Department of Agriculture and Consumer Services (FDACS) for quinclorac in 2007 to allow expanded research in aquatic systems.

Topramezone is labeled for postemergence weed control in field corn, sweet corn, and popcorn (Zea mays). Topramezone rapidly degrades to the metabolite $[3-(4,5-$ dihydro-5-hydroxy-isoxazol-3-yl)-4methanesulfonyl-2-methyl-phenyl]-(5hydroxy-1-methyl-1H-pyrazol-4-yl)methanone (M670H02) and inhibits the enzyme 4-hydroxyphenylpyruvate dioxygenase (HPPD) (USEPA, 2005). This results in disruption of photosynthesis and carotenoid formation and damages membrane structural integrity \{[Pest Management Regulatory Agency (PMRA)], 2006\}. Topramezone is currently being evaluated for aquatic use under a Florida EUP issued in 2008.

\begin{tabular}{llll}
\hline $\begin{array}{l}\text { Units } \\
\begin{array}{l}\text { To convert U.S. to SI, } \\
\text { multiply by }\end{array}\end{array}$ & U.S. unit & SI unit & $\begin{array}{l}\text { To convert SI to U.S., } \\
\text { multiply by }\end{array}$ \\
\hline 29.5735 & $\mathrm{fl} \mathrm{oz}$ & $\mathrm{mL}$ & 0.0338 \\
3.7854 & $\mathrm{gal}$ & $\mathrm{L}$ & 0.2642 \\
2.54 & inch(es) & $\mathrm{cm}$ & 0.3937 \\
16.3871 & $\mathrm{inch}^{3}$ & $\mathrm{~cm}^{3}$ & 0.0610 \\
28.3495 & $\mathrm{oz}$ & $\mathrm{g}$ & 0.0353 \\
1 & $\mathrm{ppb}$ & $\mu \mathrm{g} \cdot \mathrm{L}^{-1}$ & 1 \\
1 & $\mathrm{ppm}$ & $\mathrm{mg} \cdot \mathrm{L}^{-1}$ & 1 \\
$\left({ }^{\circ} \mathrm{F}-32\right) \div 1.8$ & ${ }^{\circ} \mathrm{F}$ & ${ }^{\circ} \mathrm{C}$ & $\left(1.8 \times{ }^{\circ} \mathrm{C}\right)+32$ \\
& & &
\end{tabular}


Imazamox is labeled for postemergence weed control in aquatic and terrestrial systems. It is an imidazole derivative in the imidazolinone class of herbicides and is also referred to as the ammonium salt of imazamox (Kegley et al., 2008). Imazamox inhibits the synthesis of acetohydroxyacid, which disrupts biosynthesis of the amino acids leucine, isoleucine, and valine (BASF, 2008). Imazamox is labeled for postemergence weed control in alfalfa (Medicago sativa), soybean (Glycine max), and edible legumes including pea (Pisum sativum) and bean (Phaseolus vulgaris), and in Mar. 2008, it received a full USEPA Section 3 aquatic use label for use in aquatic systems (BASF, 2008). Irrigation with imazamox-treated water is allowed when the concentration is $\leq 50 \mathrm{ppb}$.

Penoxsulam is labeled for postemergence weed control in warm- and cool-season turf and in dry-seeded or water-seeded rice. Penoxsulam is a triazolopyrimidine sulfonamide and also acts as an acetolactate synthase (ALS) inhibitor, which interferes with synthesis of the amino acids valine, leucine, and isoleucine (SePRO, 2007). Penoxsulam is sold under a number of trade names and in July 2007 received a USEPA Section 3 registration for use as Galleon $\mathrm{SC}^{\mathrm{TM}}$ (SePRO, Carmel, IN) in aquatic systems (SePRO, 2007). Irrigation of food crops other than rice with $\mathrm{Gal}$ leon $\mathrm{SC}^{\mathrm{TM}}$-treated water is prohibited at concentrations of $>1.0 \mathrm{ppb}$, whereas turf and rice irrigation is prohibited when the concentration of penoxsulam is $\geq 30 \mathrm{ppb}$. The label further instructs applicators to contact SePRO regarding the use of penoxsulam-treated water for irrigation of ornamentals other than turf.
The USEPA regulates the amount of pesticide residue in or on food crops irrigated with herbicidetreated water, but does not address residue amounts in ornamental plants (USEPA, 2003). Previous research has reported the effects of other aquatic herbicides on ornamental species (e.g., Andrew et al., 2003; Koschnick et al., 2005a, 2005b; Mudge et al., 2007; Mudge and Haller, 2009), but little is known regarding the effects of quinclorac, topramezone, imazamox, and penoxsulam on bedding plants. Homeowners living adjacent to canals and lakes often use water from these sources to irrigate turf and bedding plants. Therefore, knowledge of the possible phytotoxicity of these herbicides is important to determine appropriate irrigation restrictions on turf, ornamentals, and bedding plants. The objective of these experiments
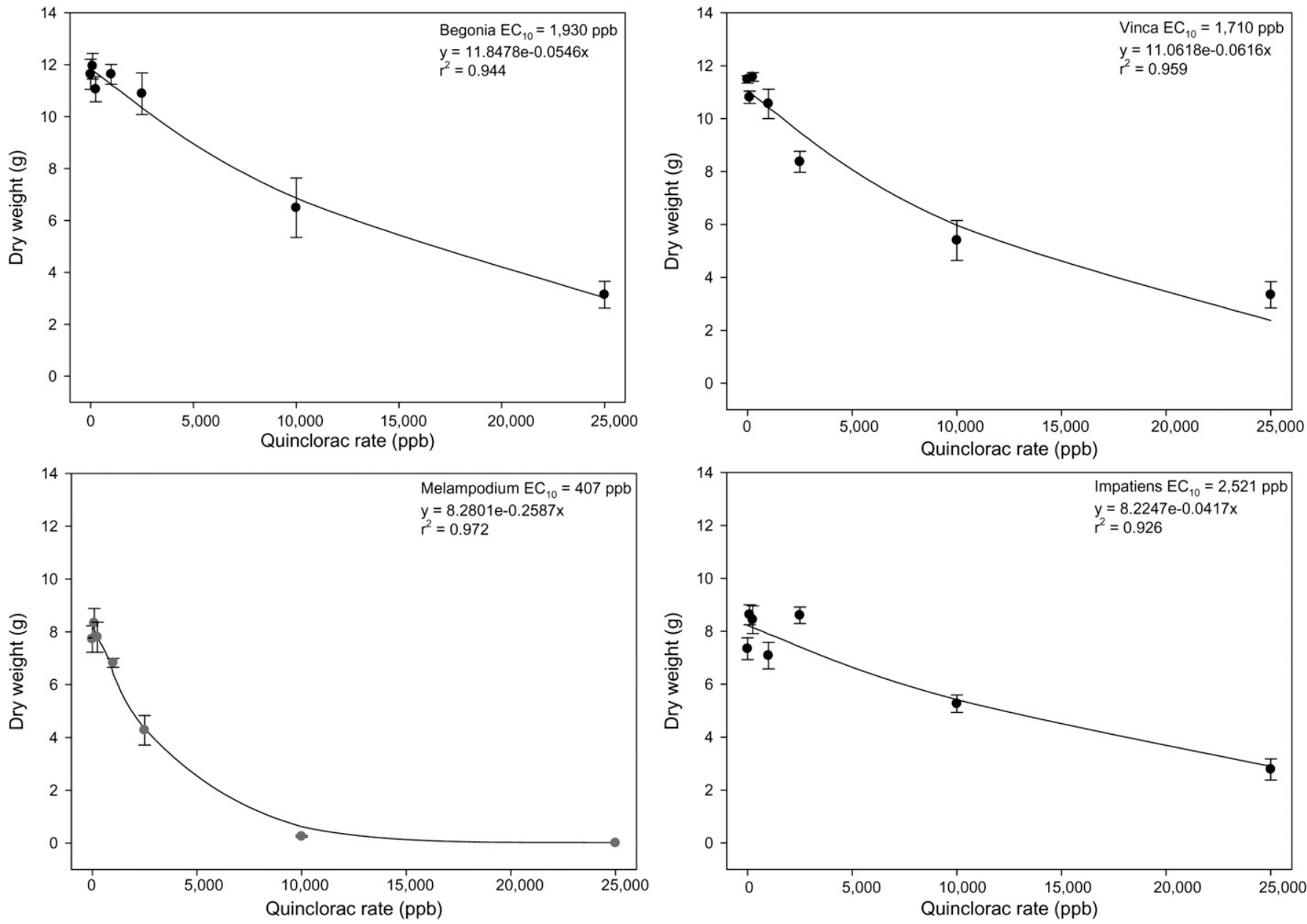

Fig. 1. Dry weight of 'Cocktail Whiskey' begonia, 'Sun Devil Extreme' vinca, 'Million Gold' melampodium, and 'Super Elfin' impatiens treated with quinclorac. Plants were irrigated with quinclorac solutions four times during a 10 -d period and were then irrigated with tap water for an additional $17 \mathrm{~d}$ before harvest. Herbicide rates were $0,100,250,1000,2500,10,000$, and $25,000 \mathrm{ppb} . \mathrm{EC}_{10}=$ effective concentration of herbicide expected to cause a $10 \%$ reduction in dry weight compared with control plants; $1 \mathrm{ppb}=1 \mu \mathrm{g} \cdot \mathrm{L}^{-1}, 1 \mathrm{~g}=0.0353 \mathrm{oz}$ 
was to evaluate the effects of these herbicides on selected bedding plants and to provide further information for developing irrigation restrictions that will limit damage to bedding plants in landscapes that are irrigated with herbicide-treated water.

\section{Materials and methods}

Begonia, vinca, melampodium, and impatiens were purchased in Apr. 2008 from a wholesale nursery in LaCrosse, FL. All plants were purchased and maintained in 3.5-inch traditional square pots $(3.5 \times 3.5 \times$ 3.75 inches; 46 inch $^{3}$ ) filled with Fafard IP Mix (composed of Canadian sphagnum peatmoss, perlite, a wetting agent, starter nutrients, and dolomitic limestone; Conrad Fafard, Agawam, MA) and were kept in an unlit greenhouse (temperature range $20-35^{\circ} \mathrm{C}$ ) at the University of Florida Center for Aquatic and Invasive Plants in Gainesville for $2 \mathrm{~d}$ before treatment. Experimental plants were healthy, actively growing, "gardenready," and were selected for uniform growth and height to minimize variation. Average initial heights of plants were $17,20,12.5$, and $12.5 \mathrm{~cm}$ for begonia, vinca, melampodium, and impatiens, respectively. Each container was overhead irrigated $24 \mathrm{~h}$ before herbicide treatment with around 360 $\mathrm{mL}$ of tap water (equivalent to 0.5 inch), which completely wet all foliage and saturated the potting medium.

Six concentrations of each herbicide (quinclorac and topramezone from 100 to $25,000 \mathrm{ppb}$; imazamox from 250 to $10,000 \mathrm{ppb}$; and penoxsulam from 25 to $5000 \mathrm{ppb}$ ) and a tap-water control were compared for all four bedding plants. These experimental rates were chosen to include the highest proposed aquatic use rates (500 ppb for quinclorac and imazamox; $50 \mathrm{ppb}$ for topramezone; and $150 \mathrm{ppb}$ for penoxsulam) and were increased to encompass much higher concentrations. These ranges were chosen to ensure that the maximum experimental rate of each herbicide caused near-total mortality of the bedding plants tested, which results in more accurate calculation of $\mathrm{EC}_{10}$ values (the effective concentration of herbicide expected to cause a $10 \%$ reduction in dry weight compared with control plants) derived from regression analysis. Each herbicide/rate/ species combination was replicated three times with three single-plant pots per replicate and treatments were applied in a completely randomized design. Each replicate was maintained in an aluminum pan $(12.75 \times 10.5 \times$ 3.25 inches deep) to allow collection and disposal of excess treatment solutions. All plants within a single pan were overhead irrigated with $1.084 \mathrm{~L}$ of treatment solution (equivalent to 0.5 inch per pan per irrigation), which completely wet all foliage and saturated the potting medium. Most treatment solutions were immediately absorbed by the potting medium; excess solution collected in pans was rarely more than $1 \mathrm{~cm}$ deep and was removed from the pans 12 to $24 \mathrm{~h}$ after treatment. Plants were treated four times over a $10-\mathrm{d}$ period (on days $1,4,8$, and 11) to simulate a twiceweekly irrigation regime, with fresh treatment solutions prepared before each irrigation event.

Plants were maintained until day 28 (17 d after application of the final

Table 1. Effective concentration of herbicide expected to cause a $10 \%$ reduction in dry weight compared with control plants $\left(\mathrm{EC}_{10}\right), 95 \%$ confidence interval (CI), and regression equations for visual rating and plant height of 'Cocktail Whiskey' begonia, 'Sun Devil Extreme' vinca, 'Million Gold' melampodium, and 'Super Elfin' impatiens treated with the herbicides quinclorac, topramezone, imazamox, and penoxsulam. Plants were irrigated with herbicide solutions four times during a 10-d period and were then irrigated with tap water for an additional $17 \mathrm{~d}$ before harvest. Herbicide rates were $0,100,250,1000,2500$, 10,000 , and $25,000 \mathrm{ppb}$ (quinclorac and topramezone); 0, 250,500, 1000, 2500,5000 , and 10,000 (imazamox), or $0,25,100,250,500,1000$, and 5000 ppb (penoxsulam); $1 \mathrm{ppb}=1 \mu \mathrm{g} \cdot \mathrm{L}^{-1}$.

\begin{tabular}{|c|c|c|c|}
\hline Quinclorac & $\mathrm{EC}_{10}[\mathrm{ppb}(95 \% \mathrm{CI})]$ & Regression equation & $\mathbf{r}^{2}$ \\
\hline Begonia visual & $1570(1350-1880)$ & $y=9.5932 e-0.0669 x$ & 0.992 \\
\hline Vinca visual & $1700(1260-2590)$ & $y=8.2163 e-0.0620 x$ & 0.997 \\
\hline Melampodium visual & $240(210-260)$ & $\mathrm{y}=10.2599 \mathrm{e}-0.4456 \mathrm{x}$ & 0.997 \\
\hline Impatiens visual & $990(660-1940)$ & $y=7.2677 e-0.1066 x$ & 0.995 \\
\hline Begonia ht & $2930(2460-3650)$ & $y=17.4998 e-0.0359 x$ & 0.971 \\
\hline Vinca ht & $6590(4970-9760)$ & $y=16.8118 e-0.0160 x$ & 0.926 \\
\hline Melampodium ht & $490(410-620)$ & $y=13.4553 e-0.2134 x$ & 0.994 \\
\hline Impatiens ht & $14,350(6270-50,170)$ & $y=10.1995 e-0.00734 x$ & 0.692 \\
\hline Topramezone & $\mathrm{EC}_{10}[\mathrm{ppb}(95 \% \mathrm{CI})]$ & Regression equation & $\mathbf{r}^{2}$ \\
\hline Begonia visual & $2650(2200-3370)$ & $y=9.4733 e-0.0397 x$ & 0.994 \\
\hline Vinca visual & $280(1$ & $y=8.3$ & 0.998 \\
\hline Melampodium visual & $1480(1000-2860)$ & $\mathrm{y}=7.8$ & 0.974 \\
\hline Impatiens visual & $3160(2210-5600)$ & $y=8.6744$ & 0.986 \\
\hline Begonia ht & $10,030(7530-14,880)$ & $9 e-0.0105 x$ & 0.884 \\
\hline Vinca ht & $8040(5730-13,370)$ & $\mathrm{y}=17.2884 \mathrm{e}-0.0131 \mathrm{x}$ & 0.957 \\
\hline Melampodium ht & $5270(3500-10,560)$ & $\mathrm{y}=11.3145 \mathrm{e}-0.0200 \mathrm{x}$ & 0.954 \\
\hline Impatiens ht & $6800(4620-12,820)$ & $y=9.8276 e-0.0155 x$ & 0.946 \\
\hline Imazamox & $\mathrm{EC}_{10}[\mathrm{ppb}(95 \% \mathrm{CI})]$ & Regression equation & $\mathbf{r}^{2}$ \\
\hline Begonia visual & $1670(1280-2380)$ & $y=8.5$ & 0.992 \\
\hline ca visual & $4050(2470-11,440)$ & $y=7.8789 e-0.0260 x$ & 0.960 \\
\hline ampodium visual & $580(440-8$ & $\mathrm{y}=8.3037 \mathrm{e}-0.1$ & 0.985 \\
\hline atiens visual & $1970(1430-3200)$ & $\mathrm{y}=8.2175 \mathrm{e}-0.0534 \mathrm{x}$ & 0.973 \\
\hline & $2820(1790-6540)$ & $54 \mathrm{e}-0.0374 \mathrm{x}$ & 0.955 \\
\hline ca ht & $4120(2940-6890)$ & $y=21.8537 e-0.0256 x$ & 0.880 \\
\hline podium ht & $2410(1720-4040)$ & $y=12.3063 e-0.0437 x$ & 0.866 \\
\hline Impatiens ht & $5660(2660-44,080)$ & $\mathrm{y}=12.1530 \mathrm{e}-0.0186 \mathrm{x}$ & 0.881 \\
\hline Penoxsulam & $\mathrm{EC}_{10}[\mathrm{ppb}(95 \% \mathrm{CI})]$ & Regression equation & $\mathbf{r}^{2}$ \\
\hline & $1950(1040-14,820)$ & $\mathrm{y}=8$. & 0.940 \\
\hline Vinca visual & $740(560-1100)$ & $y=8.5585 e-0.1426 x$ & 0.976 \\
\hline Melampodium visual & $10(10-10)$ & $y=9.2570 e-13.6367 x$ & 0.984 \\
\hline Impatiens visual & $110(70-200)$ & $y=8.1786 e-0.9888 x$ & 0.992 \\
\hline Begonia ht & $1940(1120-7420)$ & $y=12.7394 e-0.0542 x$ & 0.963 \\
\hline & $1610(1280-2160)$ & $\mathrm{y}=22.1340 \mathrm{e}-0.0655 \mathrm{x}$ & 0.901 \\
\hline & $20(20-30)$ & $y=13.0194 e-4.3650 x$ & 0.985 \\
\hline Impatiens ht & $1560(880-6590)$ & $y=12.3423 e-0.0676 x$ & 0.801 \\
\hline
\end{tabular}


treatment) to allow manifestation of treatment effects, and were destructively harvested before significant regrowth from apical or adventitious buds could occur. Plants were irrigated with about $360 \mathrm{~mL}$ of tap water per container as needed during the grow-out period and were fertigated on days 17 and 23 with $20 \mathrm{~N}-8.7 \mathrm{P}-$ 16.6K water-soluble fertilizer (Peter's 20-20-20; Spectrum Group, St. Louis) that supplied $200 \mathrm{ppm} \mathrm{N}$ in about $360 \mathrm{~mL}$ of tap water per container. On day 28, each replicate was assigned a visual quality rating on a scale of 0 to 10 by the lead investigator, with a score of 0 signifying plant death and a score of 10 signifying no visible damage. The height of the tallest plant of each species in each replicate was recorded and a destructive harvest was then used to collect all aboveground plant tissue. Plant tissue was placed in a forced-air oven at $90{ }^{\circ} \mathrm{C}$ for 2 weeks until a constant mass was achieved.

Data were subjected to analysis of variance and nonlinear regression using SAS (version 9.1; SAS Institute, Cary, NC). As plant size and weight was significantly different among the bedding plants tested, separate analyses were performed for each species. Regression models were used to determine $\mathrm{EC}_{10}$ values - the effective concentration of herbicide expected to cause a $10 \%$ reduction in dry weight compared with control plants. The $\mathrm{EC}_{10}$ value is conservative and was selected to represent the level at which herbicide damage might become noticeable to a homeowner (Koschnick et al., 2005b).

\section{Results and discussion}

Melampodium was the most sensitive bedding plant exposed to quinclorac (Fig. 1, Table 1), with $\mathrm{EC}_{10}$ values of $240 \mathrm{ppb}$ for visual quality, $490 \mathrm{ppb}$ for height, and $410 \mathrm{ppb}$ for dry weight. Visual quality of impatiens was reduced at $990 \mathrm{ppb}$, but height and dry weight were less affected by quinclorac, with $\mathrm{EC}_{10}$ values of 14,350 and $2,520 \mathrm{ppb}$, respectively. Quinclorac reduced visual quality, height, and dry weight of begonia by $10 \%$ at 1570,2930 , and $1930 \mathrm{ppb}$, respectively, while these parameters in vinca were reduced by $10 \%$ at 1700,6590 , and $1710 \mathrm{ppb}$, respectively. Plant height was less affected by quinclorac than visual quality or dry weight in all four species; within each species, $\mathrm{EC}_{10}$ values for height were higher than those for visual quality or dry weight. These data show a wide variance in tolerance to quinclorac in irrigation water, but average visual quality of all bedding plants declined as the concentration of quinclorac increased (Table 2). The calculated visual $\mathrm{EC}_{10}$ values varied from 240 to $1700 \mathrm{ppb}$, whereas dry weight $\mathrm{EC}_{10}$ values ranged from 410 to $2520 \mathrm{ppb}$ across the four species. The current EUP label for quinclorac allows the use of this herbicide at concentrations up to $500 \mathrm{ppb}$. If concentrations of quinclorac remain this high, it is reasonable to expect that water use restrictions will need to be placed on this product to avoid damage to nontarget plants.

Visual quality and dry weight of vinca were reduced by exposure to 280 and $110 \mathrm{ppb}$, respectively, of topramezone (Fig. 2, Table 1), but height of vinca was not reduced at concentrations of less than $8040 \mathrm{ppb}$. Topramezone reduced visual quality, height, and dry weight of melampodium at 1480 , 5270, and $1590 \mathrm{ppb}$, respectively, while these parameters in begonia were reduced at 2,650, 10,030 , and 2,320 ppb, respectively. Impatiens was relatively tolerant of topramezone, with $\mathrm{EC}_{10}$ values of 3160,6800 , and $4680 \mathrm{ppb}$ for visual quality, height, and dry weight, respectively. Similar to the results from quinclorac, plant height was affected less by topramezone than visual quality or dry weight in all four species. Vinca was the most sensitive of the four species to topramezone (based on visual quality), but was most tolerant of the four species to quinclorac. The current EUP label for topramezone allows the use of this product at concentrations up to $50 \mathrm{ppb}$ for control of submersed weeds. Vinca was the most sensitive bedding plant species evaluated against topramezone and showed reductions in visual quality and dry weight at 280 and $110 \mathrm{ppb}$, respectively - rates that exceed the proposed maximum label rate of $50 \mathrm{ppb}$ for aquatic weed control. In addition,

Table 2. Average visual ratings of 'Cocktail Whiskey' begonia, 'Sun Devil Extreme' vinca, 'Million Gold' melampodium, and 'Super Elfin' impatiens treated with the herbicides quinclorac, topramezone, imazamox, and penoxsulam. Plants were irrigated with herbicide solutions four times during a 10-d period and were then irrigated with tap water for an additional $17 \mathrm{~d}$ before harvest. Visual quality was rated on a scale of 0 to 10 , with a score of 0 signifying plant death and a score of 10 signifying no visible damage.

\begin{tabular}{|c|c|c|c|c|c|c|c|}
\hline \multirow[b]{2}{*}{ Species } & \multicolumn{7}{|c|}{ Quinclorac $(\mathrm{ppb})^{\mathrm{z}}$} \\
\hline & 0 & 100 & 250 & 1000 & 2500 & 10,000 & 25,000 \\
\hline Begonia & 10.0 & 9.0 & 9.5 & 9.0 & 7.0 & 4.5 & 2.5 \\
\hline Vinca & 10.0 & 8.0 & 8.0 & 7.0 & 5.5 & 4.0 & 2.5 \\
\hline Melampodium & 10.0 & 10.0 & 9.0 & 8.0 & 3.0 & 0.0 & 0.0 \\
\hline \multirow[t]{3}{*}{ Impatiens } & 10.0 & 7.0 & 6.0 & 5.5 & 4.0 & 3.0 & 1.0 \\
\hline & \multicolumn{7}{|c|}{ Topramezone (ppb) } \\
\hline & $\mathbf{0}$ & 100 & 250 & 1000 & 2500 & 10,000 & 25,000 \\
\hline Begonia & 10.0 & 10.0 & 10.0 & 8.5 & 7.5 & 6.0 & 4.0 \\
\hline Vinca & 10.0 & 8.0 & 6.5 & 4.5 & 4.0 & 2.5 & 2.0 \\
\hline Melampodium & 10.0 & 9.0 & 7.0 & 5.5 & 5.0 & 4.0 & 2.0 \\
\hline \multirow[t]{3}{*}{ Impatiens } & 10.0 & 9.5 & 9.0 & 8.0 & 6.0 & 5.0 & 5.0 \\
\hline & \multicolumn{7}{|c|}{$\operatorname{Imazamox}(p p b)$} \\
\hline & $\mathbf{0}$ & 250 & 500 & 1000 & 2500 & 5000 & 10,000 \\
\hline Begonia & 10.0 & 8.0 & 7.5 & 8.0 & 7.0 & 6.0 & 5.0 \\
\hline Vinca & 9.5 & 8.0 & 7.0 & 7.0 & 7.0 & 7.0 & 6.0 \\
\hline Melampodium & 10.0 & 8.0 & 7.0 & 6.0 & 4.5 & 3.0 & 2.5 \\
\hline \multirow[t]{3}{*}{ Impatiens } & 10.0 & 7.5 & 7.5 & 7.0 & 6.5 & 6.0 & 5.0 \\
\hline & \multicolumn{7}{|c|}{ Penoxsulam (ppb) } \\
\hline & 0 & 25 & 100 & 250 & 500 & 1000 & 5000 \\
\hline Begonia & 10.0 & 9.0 & 7.5 & 7.5 & 7.0 & 6.5 & 6.5 \\
\hline Vinca & 9.5 & 9.0 & 8.5 & 8.0 & 7.5 & 6.0 & 5.0 \\
\hline Melampodium & 10.0 & 5.5 & 3.0 & 1.0 & 0.0 & 0.0 & 0.0 \\
\hline Impatiens & 10.0 & 8.0 & 7.0 & 5.0 & 4.0 & 4.0 & 2.0 \\
\hline
\end{tabular}

${ }^{\mathrm{z}} 1 \mathrm{ppb}=1 \mu \mathrm{g} \cdot \mathrm{L}^{-1}$. 

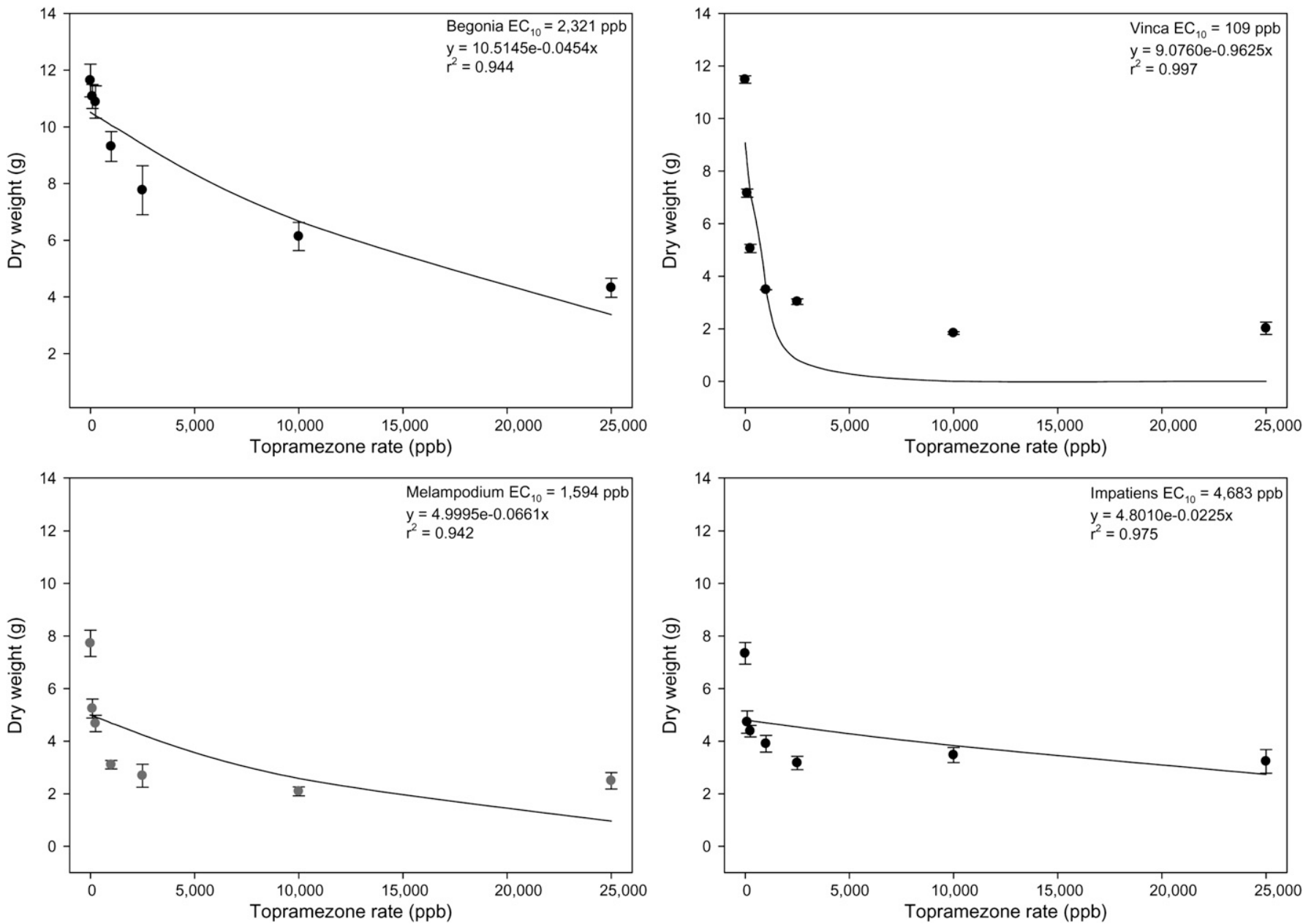

Fig. 2. Dry weight of 'Cocktail Whiskey' begonia, 'Sun Devil Extreme' vinca, 'Million Gold' melampodium, and 'Super Elfin' impatiens treated with topramezone. Plants were irrigated with topramezone solutions four times during a 10-d period and were then irrigated with tap water for an additional $17 \mathrm{~d}$ before harvest. Herbicide rates were $0,100,250,1000,2500$, 10,000 , and $25,000 \mathrm{ppb} . \mathrm{EC}_{10}=$ effective concentration of herbicide expected to cause a $10 \%$ reduction in dry weight compared with control plants; $1 \mathrm{ppb}=1 \mu \mathrm{g} \cdot \mathrm{L}^{-1}, 1 \mathrm{~g}=0.0353 \mathrm{oz}$.

average visual quality of all bedding plants declined as the concentration of topramezone increased (Table 2). These data suggest that water-use restrictions should not be necessary if topramezone is applied at or below the recommended label rate for aquatic weed control.

Melampodium was the most sensitive bedding plant exposed to the ALS inhibitor imazamox (Fig. 3, Table 1), with $\mathrm{EC}_{10}$ values of 580 , 2410 , and $610 \mathrm{ppb}$ for visual quality, height, and dry weight, respectively. Visual quality and dry weight of begonia were reduced at 1670 and 1080 ppb, respectively, but a $10 \%$ reduction in height required an imazamox concentration of $2820 \mathrm{ppb}$. Imazamox reduced visual quality, height, and dry weight of impatiens at 1970 , 5660 , and $3360 \mathrm{ppb}$, respectively, while these same parameters in vinca were reduced at 4050, 4120, and $2930 \mathrm{ppb}$. $\mathrm{EC}_{10}$ values for height were again higher than those for visual quality or dry weight within each species. Also, average visual quality of all bedding plants declined as the concentration of imazamox increased (Table 2). The maximum label rate for use of imazamox in water is $500 \mathrm{ppb}$, and the label for this herbicide states that water containing $\geq 50 \mathrm{ppb}$ of imazamox cannot be used for irrigation. At this concentration, visual phytotoxic effects and 10\% reductions in plant height and dry weight are unlikely to occur in the tested species, even when subjected to four irrigations over a 2 -week period.

Melampodium was highly sensitive to the ALS inhibitor penoxsulam (Fig. 4, Table 1), with $\mathrm{EC}_{10}$ values of $10 \mathrm{ppb}$ for visual quality and dry weight and $20 \mathrm{ppb}$ for height. Visual quality and dry weight of impatiens were reduced at 110 and $620 \mathrm{ppb}$, respectively, but height was less affected, with an $\mathrm{EC}_{10}$ value of 1560 ppb. Penoxsulam reduced visual quality, height, and dry weight of vinca at 740,1610 , and $1220 \mathrm{ppb}$, respectively, while these parameters in begonia were impacted at 1950, 1940, and $490 \mathrm{ppb}$, respectively. Melampodium was extremely sensitive to penoxsulam-treated water when used for irrigation of this species. Most bedding plants tolerated four irrigations of most of these herbicides at $>100 \mathrm{ppb}$, but the $\mathrm{EC}_{10}$ for penoxsulam on melampodium was only $10 \mathrm{ppb}$ for visual quality and dry weight. In addition, average visual quality of all bedding plants declined as the concentration of penoxsulam increased (Table 2). The maximum label rate of penoxsulam is currently 

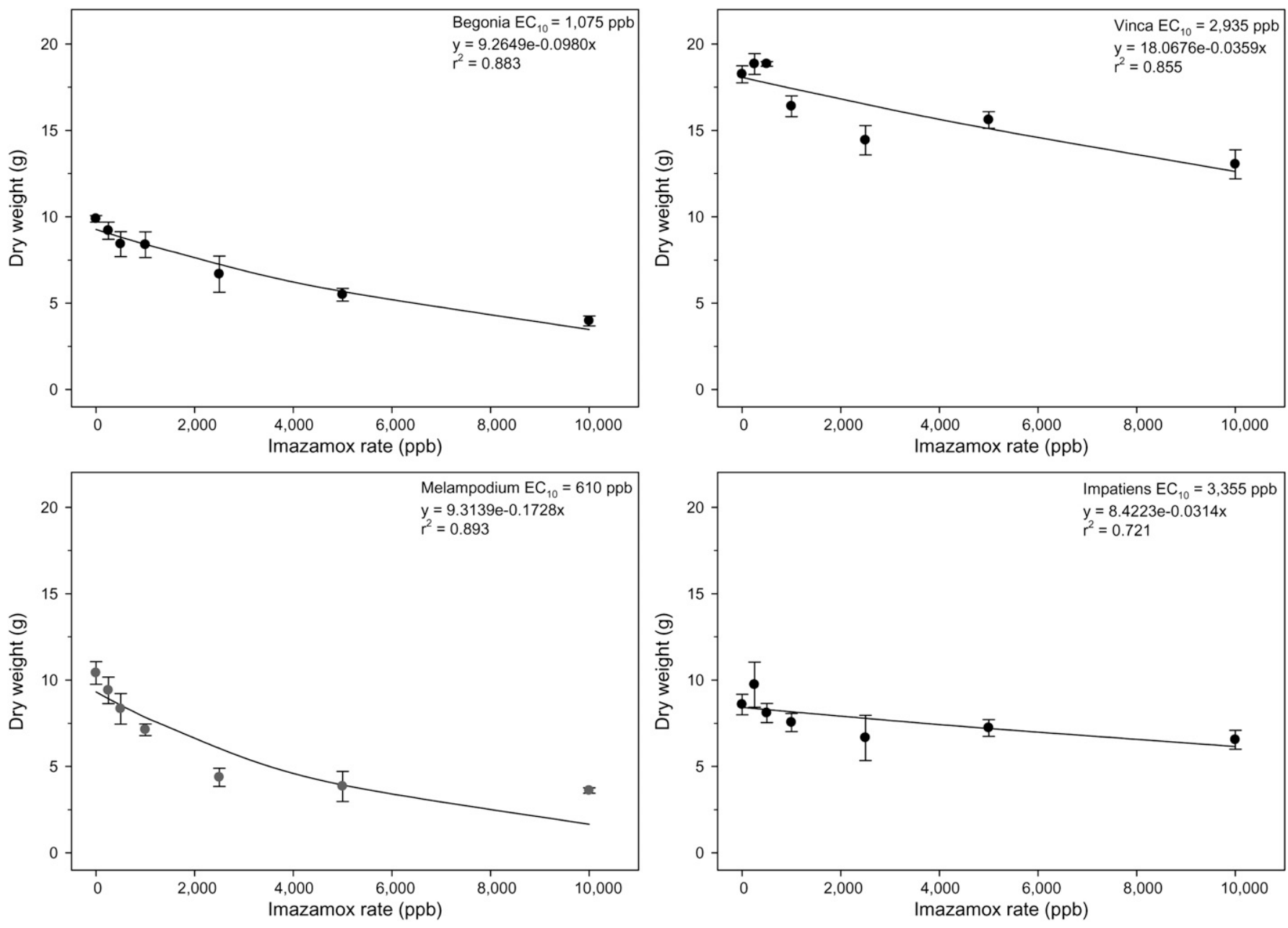

Fig. 3. Dry weight of 'Cocktail Whiskey' begonia, 'Sun Devil Extreme' vinca, 'Million Gold' melampodium, and 'Super Elfin' impatiens treated with the acetolactate synthase (ALS) inhibitor imazamox. Plants were irrigated with imazamox solutions four times during a 10-d period and were then irrigated with tap water for an additional $17 \mathrm{~d}$ before harvest. Herbicide rates were $0,250,500,1000,2500,5000$, and $10,000 \mathrm{ppb}$. $\mathrm{EC}_{10}=$ effective concentration of herbicide expected to cause a $10 \%$ reduction in dry weight compared with control plants; $1 \mathrm{ppb}=1 \mu \mathrm{g} \cdot \mathrm{L}^{-1}, 1 \mathrm{~g}=0.0353 \mathrm{oz}$.

$150 \mathrm{ppb}$ per annual growth cycle, and irrigation of ornamental plants other than turfgrass is restricted until penoxsulam concentration is $\leq \mathrm{l} p \mathrm{pp}$ (SePRO, 2007). These data suggest that current water-use restrictions are adequate to prevent damage to sensitive species like melampodium.

\section{Conclusions}

The four herbicides tested in these experiments included one auxin (quinclorac), one photosynthetic disrupter/ bleaching agent (topramezone), and two ALS inhibitors (imazamox and penoxsulam), and a range of susceptibilities to these herbicides was anticipated. Melampodium was clearly the most sensitive of the bedding plants to quinclorac, imazamox, and penoxsulam, whereas vinca was the most sensitive species to topramezone. The plants tested in these experiments may have eventually grown out of herbicide damage symptoms if allowed enough time; however, it is possible that homeowners would assume that plants would not recover and demand replacement of plants damaged after irrigation with herbicide-treated water. In addition, repeated irrigations with the same treated water would likely cause damage over an extended length of time because the half-lives of these herbicides range from $20 \mathrm{~d}$ to greater than $60 \mathrm{~d}$. Finally, penoxsulam and topramezone remain active in the soil for long periods of time, therefore bedding plants irrigated with water containing these herbicides would be challenged in the long term as well.

Plant height was not a good indicator of plant susceptibility to these herbicides. Fast-growing bedding plant species like those tested in this study often "grow out" of herbicide-induced damage during the 17-d period after application of final herbicide treatments, particularly after treatment with herbicides at low concentrations. Visual ratings, though subjective, were more closely aligned with dry weight data and may be more relevant to establishing possible irrigation restrictions on water treated for aquatic weed control. Irrigation restrictions on the currently labeled herbicides imazamox, penoxsulam, and topramezone appear to adequately address use of treated waters at recommended concentrations for irrigation of these bedding plant species. However, irrigation restrictions for quinclorac are needed to prevent damage to sensitive species such as melampodium. 

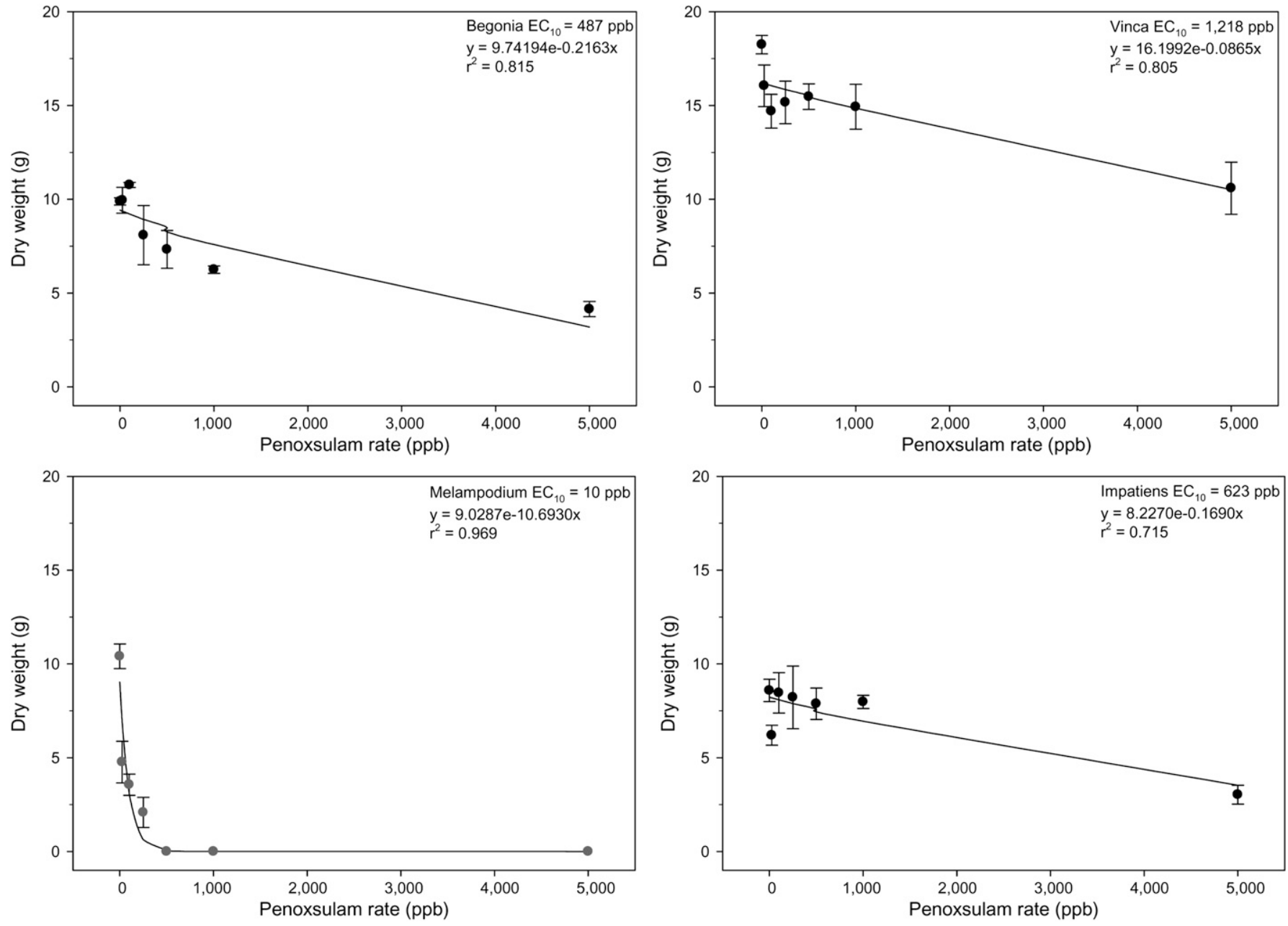

Fig. 4. Dry weight of 'Cocktail Whiskey' begonia, 'Sun Devil Extreme' vinca, 'Million Gold' melampodium, and 'Super Elfin' impatiens treated with the acetolactate synthase (ALS) inhibitor penoxsulam. Plants were irrigated with penoxsulam solutions four times during a 10 -d period and were then irrigated with tap water for an additional $17 \mathrm{~d}$ before harvest. Herbicide rates were $0,25,100,250,500,1000$, and $5000 \mathrm{ppb} . \mathrm{EC}_{10}=$ effective concentration of herbicide expected to cause a $10 \%$ reduction in dry weight compared with control plants; $1 \mathrm{ppb}=1 \mu \mathrm{g} \cdot \mathrm{L}^{-1}, 1 \mathrm{~g}=0.0353 \mathrm{oz}$.

\section{Literature cited}

Andrew, W., W.T. Haller, and D.G. Shilling. 2003. Response of st. augustinegrass to fluridone in irrigation water. J. Aquat. Plant Manage. 41:61-63.

BASF. 2008. Clearcast herbicide: Technical bulletin. 18 Aug. 2008. <http:// www.vmanswers.com/lib/PDF/2475_ clearcast_tb.pdf>.

Grossmann, K. 1998. Quinclorac belongs to a new class of highly selective auxin herbicides. Weed Sci. 46:707-716.

Kegley, S.E., B.R. Hill, S. Orme, and A.H. Choi. 2008. PAN pesticide database. 18 Aug. 2008. <http://pesticideinfo.org/ Detail_Chemical.jsp?Rec_Id=PC40122>.

Koschnick, T.J., W.T. Haller, and A.M. Fox. 2005a. Turf and ornamental plant tolerances to endothall in irrigation water. II. Turf species. HortTechnology 15:324-329.
Koschnick, T.J., W.T. Haller, and G.E. MacDonald. 2005b. Turf and ornamental plant tolerances to endothall in irrigation water. I. Ornamental species. HortTechnology 15:318-323.

Koschnick, T.J., W.T. Haller, and L. Glasgow. 2006. Documentation of landoltia (Landoltia punctata) resistance to diquat. Weed Sci. 54:615-619.

Michel, A., R.S. Arias, B.E. Scheffler, S.O. Duke, M. Netherland, and F.E. Dayan. 2004. Somatic mutation-mediated evolution of herbicide resistance in the nonindigenous invasive plant hydrilla (Hydrilla verticillata). Mol. Ecol. 13:32293237.

Mudge, C.R. and W.T. Haller. 2009. Ornamental and row crop susceptibility to flumioxazin in overhead irrigation water. Weed Technol. 23:89-93.

Mudge, C.R., T.J. Koschnick, and W.T. Haller. 2007. Ornamental plant suscept- ibility to diquat in overhead irrigation water. J. Aquat. Plant Manage. 45:4043.

Pest Management Regulatory Agency. 2006. Regulatory note REG200609:Topramezone. 18 Aug. 2008. <http://www.pmra-arla.gc.ca/english/ $\mathrm{pdf} / \mathrm{reg} / \mathrm{reg} 2006-09-\mathrm{e} . \mathrm{pdf}>$.

SePRO. 2007. Galleon SC aquatic herbicide specimen label. 18 Aug. 2008. <http://www.sepro.com/documents/ Galleon_Label.pdf $>$.

U.S. Environmental Protection Agency. 2003. Pesticides: Regulating pesticides. Pesticide tolerances. 18 Aug. 2008. <http://www.epa.gov/pesticides/regulating/tolerances.htm>.

U.S. Environmental Protection Agency. 2005. Pesticide fact sheet: Topramezone. 18 Aug. 2008. <http://www.epa. gov/opprd001/factsheets/topramezone. pdf $>$. 